\title{
Establishment of SATREPS experimental sites in South African gold mines to monitor phenomena associated with earthquake nucleation and rupture
}

R.J. Durrheim SATREPS*, CSIR Centre for Mining Innovation, South Africa; and University of the Witwatersrand, South Africa

H. Ogasawara SATREPS*, Ritsumeikan University, Japan

M. Nakatani SATREPS*, Earthquake Research Institute, Tokyo University, Japan

Y. Yabe SATREPS*, Tohoku University, Japan

H. Kawakata SATREPS*, Ritsumeikan University, Japan

M. Naoi SATREPS*, Tokyo University, Japan

A.K. Ward First Uranium, South Africa

S.K. Murphy AngloGold Ashanti, South Africa

J. Wienand KDC Goldfields, South Africa

P. Lenegan Goldfields, South Africa

A.M. Milev SATREPS*, CSIR Centre for Mining Innovation, South Africa

O. Murakami SATREPS*, Ritsumeikan University, Japan

N. Yoshimitsu Ritsumeikan University, Japan

T. Kgarume SATREPS*, CSIR Centre for Mining Innovation, South Africa

A. Cichowicz SATREPS*, Council for Geoscience, South Africa

and the SATREPS* research group

*JST-JICA Science and Technology Research Partnership for Sustainable Development

\section{Abstract}

Mining-induced earthquakes pose a risk to workers in deep mines, while natural earthquakes pose a risk to everywhere, but especially near plate boundaries. A five year Japanese-South African collaborative project entitled 'Observational studies to mitigate seismic risks in mines' commenced in August 2010. Here we report on the achievements of the first 18 months of the project. Faults at Ezulwini, Moab-Khotsong and Driefontein gold mines considered likely to become seismically active during mining activity were modelled using pre-existing geological information supplemented by cores and camera images from new boreholes. As of 30 January 2012, about 90\% of about 70 planned boreholes totalling more than $2 \mathrm{~km}$ in length had been drilled at project sites to locate fault zones accurately and to deploy sensors. Acoustic emission sensors, accelerometers, strainmeters, and controlled seismic sources were installed to monitor the deformation of the rock mass, the accumulation of damage during the earthquake preparation phase, and changes in stress produced by the propagation of the rupture front. The suite of sensors has greater sensitivity and dynamic range than those typically used in civil or mining engineering applications, making it possible to record very small changes in stress and strain as well as violent rock mass deformation associated with large seismic events. These data sets will be integrated with measurements of stope closure, strong ground motion in stopes, and seismic data recorded by the mine-wide network. 


\section{Introduction}

Seismicity poses a serious risk to workers in deep and overstressed mines (e.g. the deep gold and platinum mines in South Africa) and people living close to plate boundaries (e.g. in Japan) and elsewhere. A five year Japan-South Africa collaborative project ( US\$3 million) entitled 'Observational studies to mitigate seismic risks in mines' (Ogasawara et al., 2009a) was launched in August 2010 (Durrheim et al., 2010). The project has three main aims, summarised in Figure 1:

1. To learn more about earthquake preparation and triggering mechanisms by deploying arrays of sensitive sensors within rock volumes where mining is likely to induce seismic activity.

2. To learn more about earthquake rupture and rockburst damage phenomena by deploying robust strong ground motion sensors close to potential fault planes and within mining excavations.

3. To upgrade the South African surface national seismic network in the mining districts.

This paper is confined to the progress achieved during the first 18 months of the project. In this time only the instruments monitoring phenomena related to earthquake nucleation and rupture were installed.

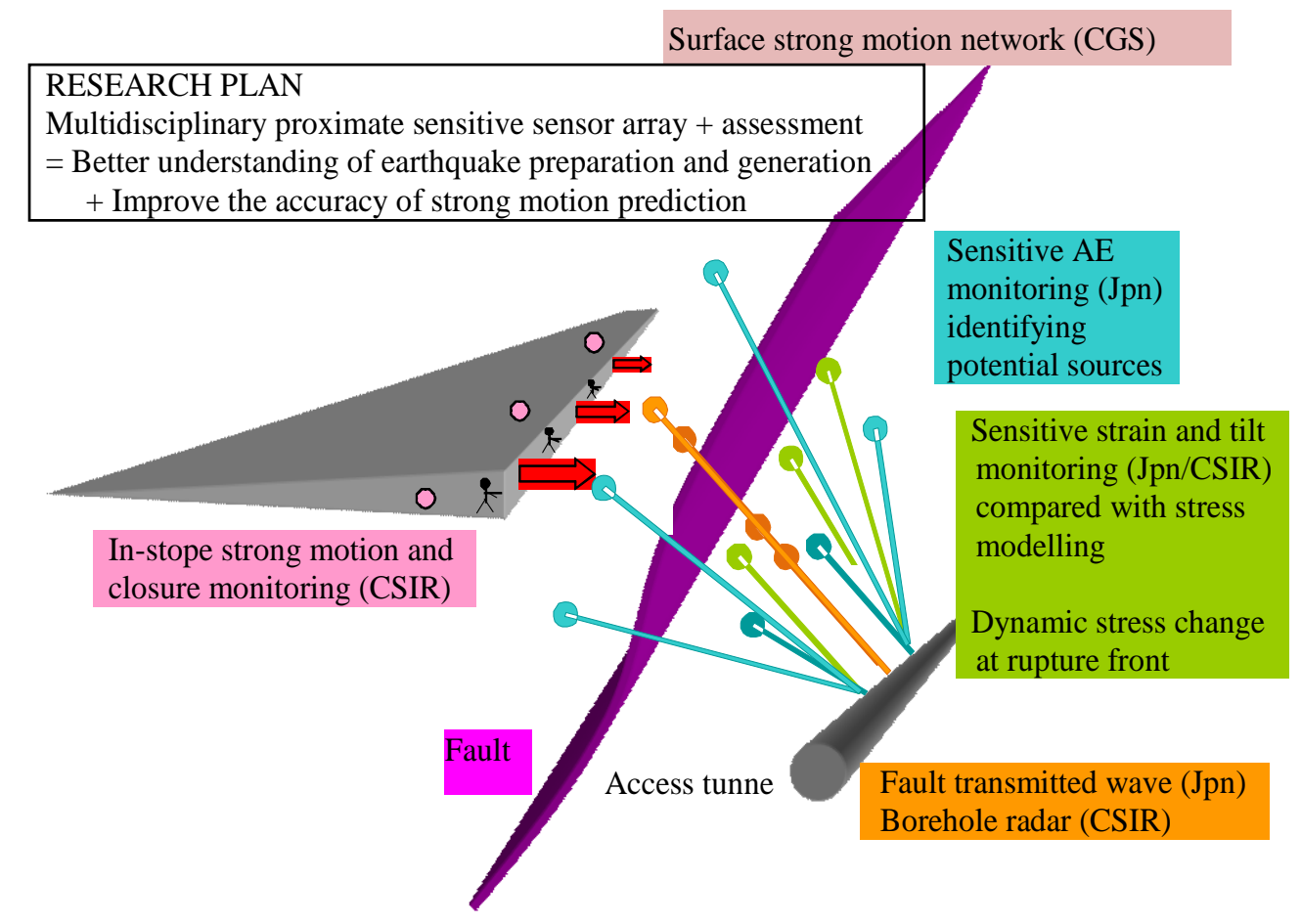

Figure 1 Schematic illustration of the research plan. Jpn: Japanese researchers, CSIR: Council for Scientific and Industrial Research, South Africa, CGS: Council for GeoScience, South Africa

The knowledge gained during the course of the project and the new infrastructure installed will contribute to efforts to improve seismic hazard assessment and mitigate the rockburst risk. The project draws on over a century of South African and Japanese research experience with respect to mining-related and tectonic earthquakes, respectively (e.g. Durrheim, 2010; Durrheim et al., 2010). A significant amount of effort was required to adapt and apply Japanese technologies to the mining environment, notably:

- laboratory techniques to detect rock fracturing at the onset of rock mass instability

- exceptionally sensitive sensors that were originally developed to monitor natural earthquakes and crustal deformation.

The project is carried out under the auspices of an inter-governmental agreement between Japan and South Africa known as the Science and Technology Research Partnership for Sustainable Development (SATREPS) and forms part of the 'Countermeasures towards Global Issues through Science and Technology 
Research Partnership' led by the Japan Science and Technology Agency (JST), an external implementation agency of Japanese Ministry of Education, Science, Technology, Culture and Sports and in the scheme of Official Development Assistance of Japanese Ministry of Foreign Affairs implemented by the Japan International Cooperation Agency (JICA) (JST, 2011). As at 30 January 2012, JICA had provided some 110 instruments with a total value of about US\$700,000, and dispatched Japanese specialists 23 times who had spent a total of about 18 months in South Africa.

\section{Scope of research}

To our knowledge this is the most ambitious observational mine-seismology research project ever undertaken in terms of the number and range of sites and sensors (see Figure 1 and Table 1).

Table 1 Summary of the SATREPS experimental sites as at January 2012

\begin{tabular}{|c|c|c|c|}
\hline Gold Mine Name & Ezulwini & Moab-Khotsong & Driefontein \\
\hline Owner & First Uranium & Anglogold Ashanti & Gold Fields \\
\hline $\begin{array}{l}\text { Ore body at } \\
\text { experimental site }\end{array}$ & $\begin{array}{l}\text { Several reef packages } \\
10 \text { s of metres thick }\end{array}$ & $\begin{array}{l}\text { Single thin tabular reef } \\
(<2 \mathrm{~m}) \text {, multiple faults }\end{array}$ & $\begin{array}{l}\text { Single thin tabular reef } \\
(<2 \mathrm{~m}) \text {, few faults }\end{array}$ \\
\hline Mining scenario & $\begin{array}{l}\text { Extraction of } 400 \mathrm{~m} \\
\text { diameter shaft pillar }\end{array}$ & $\begin{array}{l}\text { Extensive scattered } \\
\text { mining }\end{array}$ & $\begin{array}{l}\text { Sequential grid mining } \\
\text { with dip pillars }\end{array}$ \\
\hline Depth & About $1 \mathrm{~km}$ & About $3 \mathrm{~km}$ & About $3 \mathrm{~km}$ \\
\hline Concern & $\begin{array}{l}\text { Instability of faults in } \\
\text { the shaft pillar }\end{array}$ & $\begin{array}{l}\text { Instability of large } \\
\text { faults }\end{array}$ & Instability of dip pillar \\
\hline Fault characteristics & $\begin{array}{l}\text { Fault gouge a few } 10 \text { s of } \\
\text { centimetres thick }\end{array}$ & $\begin{array}{l}\text { Fault zone a few } 10 \text { s of } \\
\text { metres thick }\end{array}$ & $\begin{array}{l}\text { Fault gouge a few } \\
\text { centimetres thick }\end{array}$ \\
\hline $\begin{array}{l}\text { Applicability of research } \\
\text { to mining }\end{array}$ & $\begin{array}{l}\text { Final stage mining e.g. } \\
\text { shaft pillars, remnants }\end{array}$ & $\begin{array}{l}\text { Mining in highly } \\
\text { faulted districts }\end{array}$ & $\begin{array}{l}\text { Sequential grid mining at } \\
\text { depth }\end{array}$ \\
\hline \multicolumn{4}{|l|}{ Japanese Contributions } \\
\hline Acoustic emission & A few tens of sensors & A few tens of sensors* & - \\
\hline Strain & 2 strainmeters & 3 strainmeters* & 3 strainmeters \\
\hline Velocity \& attenuation & $1 \mathrm{Tx}, 3 \mathrm{Rx}$ & $2 \mathrm{Tx}, 3 \mathrm{Rx}^{*}$ & - \\
\hline Rupture dynamic stress & 3 instruments near fault & - & 4 instruments near fault \\
\hline Slow fault slip & 1 sensor & 2 sensors* & \\
\hline Stress & Planned & Completed & Planned \\
\hline \multicolumn{4}{|c|}{ South African Contributions } \\
\hline Borehole radar & - & Survey completed & - \\
\hline Tilt & - & 2 tiltmeters* & 2 tiltmeters* \\
\hline Stope closure & - & 1 set* $^{*}$ & 1 set* $^{*}$ \\
\hline Stope ground motion & - & 1 set accelerometers* & 1 set accelerometers* \\
\hline Surface ground motion & JICA network* & New network & JICA network* \\
\hline Status on 30 Jan 2012 & $\begin{array}{l}\mathrm{U} / \mathrm{G} \text { installation almost } \\
\text { completed }\end{array}$ & $\begin{array}{l}80 \% \text { drilling and } 20 \% \\
\text { installation completed }\end{array}$ & $\begin{array}{l}\text { Drilling \& most Japanese } \\
\text { installation completed }\end{array}$ \\
\hline
\end{tabular}

* not yet completed 
In addition to the three main research sites, a few smaller projects are being carried out at a remnant pillar in an old longwall mining area and at a regional pillar. Data from these projects will be augmented with data from the mine-wide seismic network data and stress modelling in collaboration with the mine rock engineers. It is also planned to monitor ground motion in stopes and on the surface (Durrheim et al., 2010). This equipment will be installed in 2012.

\section{1 Methodology}

Here we describe the generic procedures that were followed in establishing our underground research sites. Site-specific details are given in Section 3 of this paper. Researchers and mining company personnel, technicians and contractors associated with the activities are listed in the Acknowledgements.

- Selection of experimental sites at Moab-Khotsong, Ezulwini and Driefontein mines: In 2009 members of the project team met with geologists and mine planners to identify faults that are likely to become seismically active in 2012-2013. A lead time of at least two years was considered necessary to drill holes, install instruments, and gather background data. A suitable site must also have drilling stations (e.g. cubbies or tunnels that will not be used for several months) that are supplied with services (electricity, water, compressed air). Ideally the sites should be remote from noise sources (e.g. ventilation fans, heavy rail traffic). Underground visits were made to ensure that sites met these criteria, and to pinpoint the intersections of the potentially active fault with tunnels, cross-cuts and raises.

- Stress modelling: Numerical modelling was carried out to identify areas where significant mining-related seismicity is anticipated.

- Drilling of pilot holes to map faults: A program of exploratory drilling to delineate the fault zones that the mining faces will approach in 2012-2013 was initiated in 2010.

- Borehole core logging: The recovered core was logged, noting changes in lithology, jointing and faulting. Some sections of the core showed incipient or actual discing as a result of stress-induced fracturing. Sometimes the fault zone was difficult to detect, especially where the foot- and hangingwall rocks were indistinguishable or fault gouge was absent.

- Borehole surveying: The holes were first flushed to remove fragments of rock, then surveyed using a gyroscopic or an electromagnetic survey tool.

- Borehole imaging: The holes were photographed using a borehole camera. This was done to supplement the core logging, especially where core was lost, and to identify zones where the borehole was damaged (e.g. by breakouts) so that these sections could be avoided when installing instruments.

- Fault modelling: The borehole information was integrated with other geological information to construct a three dimensional model of the fault system.

- Experimental design: The layout of sensors was designed based on the fault model and the monitoring objectives (e.g. sensitive monitoring close to the potential rupture surface, strong motion monitoring of fault rupture).

- Borehole radar surveys: In some cases surveys were made prior to installing sensors to better image the strata and structures.

- Stress measurements: Stress measurements are vital in the evaluation of seismic hazard. Overcoring and the analysis of borehole breakouts and core discing were carried out.

- Drilling of holes and installation of sensors: Boreholes were drilled according to the experimental design, logged, surveyed and various sensors installed. These included acoustic and electromagnetic emissions, strain, tilt, strong motion, etc. 
- Calibration of stress modelling with in situ stress, strain and seismic data: Stress, strain and tilt measurements were used to improve the stress modelling. This exercise will be repeated once rock properties have been determined from drill core. The ultimate goal is to investigate how stress modelling can be used to better evaluate seismic hazard. The stress and strain measurements were also compared with seismic data recorded by the mine-wide seismic networks at the three experimental sites.

- Routine monitoring: Establishment of data recording, analysis and archiving procedures and site maintenance schedules.

\section{2 Installation of Japanese instrumentation}

Based upon their experience in South African gold mines since 1994 (e.g. Ogasawara et al., 2002, 2005, 2009a, 2009b; Nakatani et al., 2008), the Japanese researchers reviewed installation and operating procedures for each instrument. These were adapted where possible to minimise effort and cost and maximise speed.

\section{2. 1 Drilling}

The efficient drilling of a large number of research boreholes subject to the procedures and drilling equipment commonly used in South African gold mines demands careful planning. In previous studies in South African mines (Ogasawara et al., 2002) it had been attempted to drill holes large enough to accommodate sensors designed for the bigger boreholes used in Japan, but had proven to be very difficult to drill non-standard holes. Consequently, the size of the instruments was reduced, where possible, to fit BX (60 mm diameter) holes. Only the tiltmeters required larger non-standard holes. A total of eight dedicated crews were used to drill the boreholes at the three experimental sites. The $20-100 \mathrm{~m}$ holes were long enough to penetrate the fractured zone that surrounds highly-stressed tunnels. The first few metres of each hole were cased because this zone is invariably severely damaged by high stress concentrations. All holes, except those used for overcoring measurements, were down-holes for easy grouting. Grout comprised sieved cement and fine silica sand mixed with water in a specified ratio.

\subsection{Borehole survey}

The boreholes were surveyed by a contractor, Digital Surveying, using electromagnetic or Gyrosmart tools. The locations of fault intersections and sensors were surveyed with accuracy better than $10 \mathrm{~cm}$.

\subsection{Borehole viewing}

In the NELSAM project (e.g. Reches, 2006) conducted underground at Tau Tona Mine in 2006, a sophisticated borehole logging system was used, operated with a winch commonly used for larger diameter, longer holes drilled typically from surface (e.g. Lucier et al., 2009). Although the images and logs were excellent, operational difficulties were experienced with drilling and transportation. For speedy scoping of a much larger number of holes, we used a portable system with a handy borehole camera (e.g. Shinwa T-WATER $1500 \mathrm{C} 20 \mathrm{~mm}$ diameter or Raax SC-200 $38 \mathrm{~mm}$ diameter; Figure 2) with a palm-top video recorder (e.g. JXD990 with $10.9 \mathrm{~cm}$ screen, $150 \mathrm{~g}$ weight).
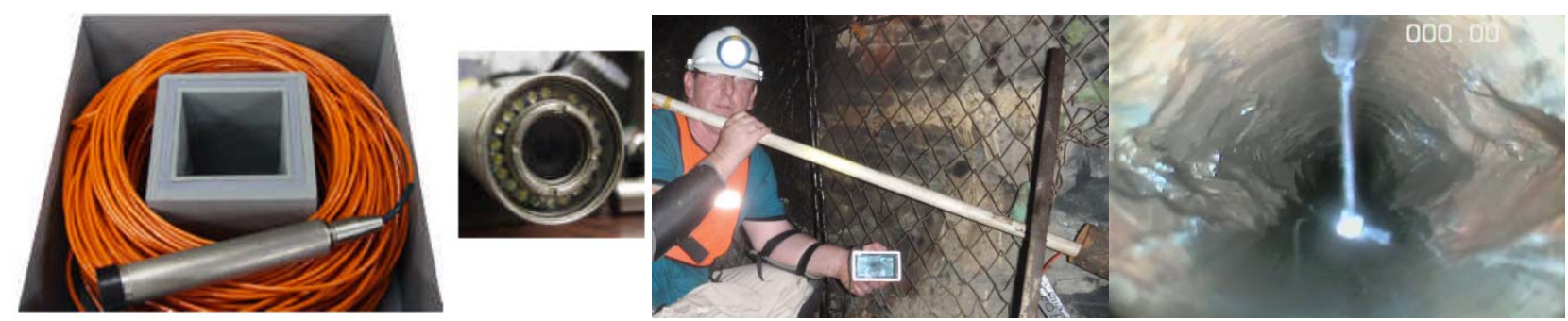

Figure 2 From left to right, a borehole camera (Raax SC-200, see Raax, 2008), a palmtop video recorder JXD990 and an example of the breakout images and a vertical marker in a BX hole 


\subsection{Fault loading and instability}

The Ishii strainmeter is an exceptionally sensitive and stable instrument, capable of detecting subtle onsets of instability as small and slow as the earth tide (typically $\sim 0.1 \mu$-strain or smaller in amplitude) that precede earthquake swarms in Japan (Ishii et al., 1997). In South African gold mines, the Ishii strainmeter has accommodated mining-induced rock mass deformation as large as $1000 \mu$-strain, delineating the entire cycle of loading and seismic stress relief as well as multiple subtle changes in strain indicating the onset of instability (e.g. Ogasawara et al., 2005, 2009b; Naoi et al., 2006). The original Ishii strainmeter was designed for NXCU holes (92 mm dia.). A slimmer smaller instrument (42 mm diameter; Figure 3) was developed for South African mines by Techno Sugaya cc.

In the normal-faulting stress regime, as in South African gold mines, a 3-component instrument is installed in a sub-horizontal borehole orientated sub-parallel to the fault (Figure 3; Ogasawara et al., 2002). Changes in shear and normal stress or ESS on the fault are derived from changes in the hole diameter. In a rock mass with a Young's modulus of $70 \mathrm{GPa}$, typical of the SATREPS research sites, the capacity and the detectability of stress change of the strainmeter in a uni-axial condition is $70 \mathrm{MPa}$ and $0.0007 \mathrm{MPa}$ ( $0.7 \mathrm{kPa}$ or 0.007 bar), respectively.

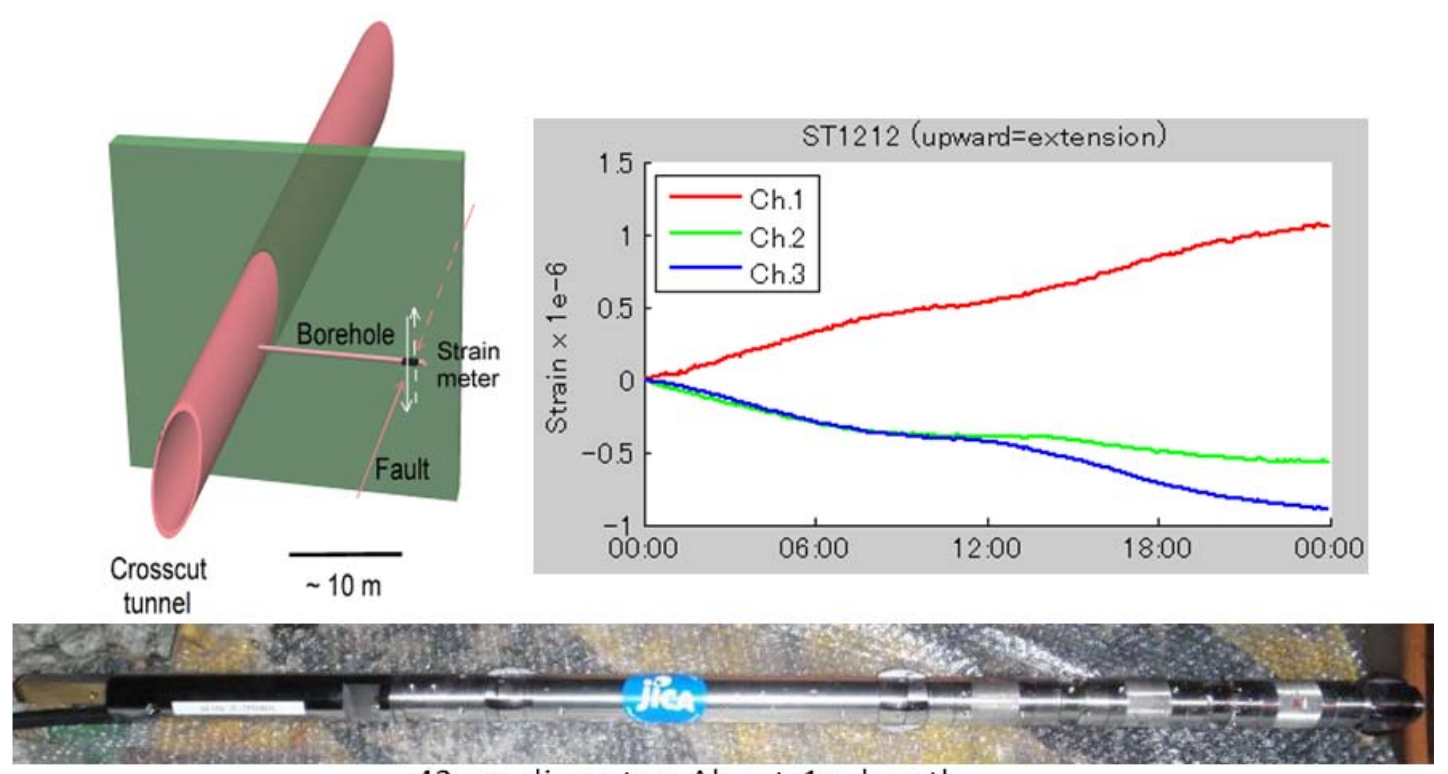

$42 \mathrm{~mm}$ diameter. About $1 \mathrm{~m}$ length.

Figure 3 Ishii strainmeter. Upper left: Schematic illustrating an ideal installation in normal-faulting stress regime to monitor shear and normal stress on a fault (Ogasawara et al., 2002). Upper right: Tidal changes measured at Ezulwini Mine. (Below) Strainmeter. The electronics are housed in the section with JICA label, while the three strain gauges are joined in series to the right

Aseismic slow events were detected at Bambanani and Mponeng mines by the Ishii strainmeter (Naoi et al., 2006; Ogasawara et al., 2009b). However, it was found that a broadband seismometer was more sensitive to the faster 'slow events' observed in the South African gold mines than the Ishii strainmeter, so it was decided to install a few broadband instruments at the SATREPS sites as well.

\subsubsection{Monitoring of acoustic emissions and seismicity}

GMuG acoustic emission (AE) systems (Gesellschaft für Materialprüfung und Geophysik, e.g. Manthei, 2005) have been installed at Ezulwini and Moab-Khotsong sites. The AE sensors are a new type that is coupled to the rock mass by grouting, enabling multiple sensors to be installed in a single hole. Consequently the SATREPS AE sensor arrays are much larger in extent and have much better 3D distribution than the Japanese-German Underground Acoustic Emission Research in South Africa (JAGUARS) site (Yabe et al., 2009). The sensing piezoelectric material is housed in a brass case of O.D. $40 \mathrm{~mm}$. A $20 \mathrm{~dB}$ preamplifier, also in a brass housing, is positioned $20 \mathrm{~cm}$ behind the sensor housing. The 
preamplifier is connected to the sensor by a rubber hose to avoid acoustic coupling. Sampling is at $500 \mathrm{kHz}$ with a $65 \mathrm{~ms}$ record length and $300 \mathrm{~ms}$ dead time after triggering. The grout-coupled sensor has much lower sensitivity above $40 \mathrm{kHz}$ than the mechanically-coupled sensors used in the JAGUARS project. While this may be a disadvantage when studying the detailed rupture dynamics of very small events, it does not degrade the network's ability to detect and locate very small events as an earthquake with $\mathrm{M}_{\mathrm{w}}-4$ has a corner frequency less than $20 \mathrm{kHz}$. The GMuG system also records the $25 \mathrm{kHz}$ and $10 \mathrm{kHz}$ triaxial accelerometers and antennae monitoring the electric field.

The installation procedures have been optimised through many experiments in Japan using a $6 \mathrm{~m}$ long transparent acrylic tube of $60 \mathrm{~mm}$ I.D. (i.e. BX hole). The grout mix consists of Ordinary Portland Cement, fine silica sand, water, an expansion agent (Gypcal), and an anti-separation agent (TF-1, TelniteCC). The anti-separation agent is necessary to avoid the formation of void space by the separated water at the high side of the shallow-plunge boreholes. Holes are inclined below the horizontal, enabling grout to be fed gravitationally through $23 \mathrm{~mm}$ PVC pipes. Experiments have found that the grout will not fill the entire diameter of the hole for more than a few meters ahead of the feeding point when the plunge is shallow. Hence, the feeding point of the PVC pipes must be set near the bottom of the borehole. Grout then must flow back upwards, breaking the viscous resistance of the grout in the borehole. Experiments and many actual installations have found that the limit for grout-feeding typical SATREPS boreholes having a plunge about $-20^{\circ}$ is about $13 \mathrm{~m}$ per shot. After the calculated amount of grout has been dispensed to the bottom, the PVC feeder pipe is taken out and the sensor is then pushed down to the target depth using a PVC installation rod. Additional sensors can be installed by repeating the procedure a day or more later, once the grout has solidified.

\subsection{Fault monitoring with transmitted waves}

It has been established in laboratory rock fracturing experiments that a change in seismic-wave velocity can be an indicator of a change in crack density or stress, and that the velocity decreases as differential stress increases (e.g. Lockner et al., 1977; Yukutake, 1989; Yoshimitsu et al., 2009). In addition, the seismic attenuation parameter $Q$ is found to decrease as differential stress increases (Yoshimitsu and Kawakata, 2011). There have also been some underground attempts to monitor velocity change in larger scale (e.g. Yukutake et al., 1988; Sano et al., 1997), successfully detecting tidal change. Changes in seismic velocity potentially associated with the onset of instability may also be detected by the seismological analysis of waveforms produced by multiplet earthquakes, ambient noise, or seismic coda waves (Brenguier et al., 2008; Chen et al., 2010; Sens-Schönfelder and Wegler, 2006).

It is also reported that the amplitude of the wave transmitted through the fault decreases just before the fault slip (e.g. Chen et al., 1993). At the Parkfield SAFOD drill site, Niu et al. (2008) deployed transmission lines at $1 \mathrm{~km}$ depth between the SAFOD holes, successfully detecting the velocity change potentially associated with M3 and M1 earthquakes. However this array was deployed away from the seismogenic volume (1 km and $5 \mathrm{~km}$ from the M1 and M3 sources, respectively) and only surface creep or GPS data were available for comparison. In a South African gold mine, Lynch (2010) detected velocity changes associated with blasting, but no rock mass deformation data were available for comparison.

One of the goals of this project is to determine whether any instability in the rock mass can be detected in seismic source volumes prior to $\mathrm{M}^{\sim 2}$ seismic events. A transmitter-receiver array was deployed across a target fault at the Ezulwini site (Kawakata et al., 2011). The recorded waveforms for each accelerometer at Ezulwini Mine have remained identical from 19 April to 7 June 2011, which shows that the system is reliable.

\subsection{Rupture front dynamic stress change monitoring system}

The characteristics of fault slip-weakening are key parameters used in numerical simulations of the generation of large earthquakes or strong motion at the seismic source. However, it has been an unresolved question how much fault displacement is needed to relieve stress sufficiently. That has been because no one has had an opportunity to do such an experiment. Boats containing both $500 \mathrm{~g} 25 \mathrm{kHz}$ 
accelerometers and quick-response high-capacity strain gauges (Figure 4) were designed to monitor fault displacement and dynamic stress change during the rupture of an $\mathrm{M} 2$ seismic event. The dynamic response and directivity of the sensors were carefully checked in a $1 \mathrm{~m}^{3}$ rock block. The boats were deployed near to a fault at the sites at Ezulwini and Driefontein mines (see 3.1 and 3.2).

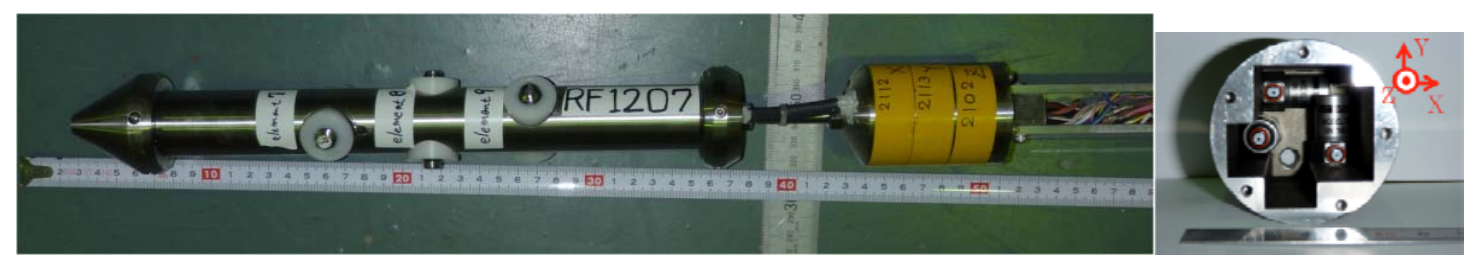

Figure 4 A sensor boat to monitor dynamic stress change (left; fast responding, high-capacity strain gauges) and fault displacement with $X-, Y-$, and $Z$ component accelerometers at rupture front (Watanabe, 2010)

\section{2. 8 BX overcoring stress measurement technique}

Stress information is important for safe mining in earthquake-prone deep mines. However, stress measurements are seldom carried out in deep South African gold mines, even though several crews are actively drilling holes for geological exploration with small pneumatic machines. One of the reasons is that the drilling diameter required for overcoring is much larger than that used for routine geological drilling. Large diameter drilling is slower, and the logistics of handling larger and heavier machines is challenging, especially in working places with few mechanised aids. The introduction of larger drilling machines also requires time-consuming procedures and skilled foremen that significantly inflate the cost.

Overcoring techniques can be used to determine the 3-D stress tensor. The Compact Conical-ended Borehole Overcoring (CCBO) technique, endorsed by ISRM (Sugawara and Obara, 1999), was originally designed for $75 \mathrm{~mm}$ diameter NX drilling. It was modified by Harumi Kato for overcoring in $60 \mathrm{~mm}$ BX holes (Ogasawara and Kato, 2012). In January 2011, the modified method was tested at a depth of about $3 \mathrm{~km}$ at Moab-Khotsong Mine using regular drilling tools (a sequence of a normal BX bit, reamer and rod) but failed. In August and September 2011 stabilisers and thin BX bits were introduced and success was achieved. The series of procedures, which include shaping the conic-borehole-bottom, gluing a 16-element strain cell and overcoring, was completed in 2.5 hours. This modified method is suitable for stress measurements at depths of 10-15 m from tunnels, and could find wide application in the early stages of a geological exploration drilling programme.

\section{3 South African instrumentation}

\section{3. 1 Tiltmeters}

Much of the rock mass response to mining is aseismic and is not recorded by acoustic emission sensors, accelerometers or geophones. We seek to monitor the whole spectrum of the rock mass response to mining. We wish to determine if there are any aseismic indicators of an imminent instability, and to quantify any changes in strain produced by seismic events. Aseismic deformation can be measured by strain and tiltmeters. Ishii strainmeters were installed within metres of the fault to measure local loading (see Section 2.2.4), while tiltmeters were installed in holes tens of meters from the fault to measure rock mass deformation. Tilt monitoring is described by Milev et al. (2010) and Durrheim et al. (2010). Large holes $(117 \mathrm{~mm})$ are required for the tiltmeter.

\section{3. 2 Borehole ground penetrating radar}

Ground penetrating radar (GPR) is a high-resolution technique that reflects short radio pulses off targets that have different electrical properties to the host rock. GPR works best in resistive host rocks containing reflective target horizons. The CSIR Aardwolf 40 borehole radar system operates at a transmitter frequency of $40-50 \mathrm{MHz}$ yielding a wavelength of $2 \mathrm{~m}$, with the transmitter and receiver antennas co-located in a borehole tool (Van Schoor et al., 2006; Vogt and Van Schoor, 2010). The quartzites of the Witwatersrand 
Basin are highly resistive and ranges of $30 \mathrm{~m}$ are reliably achieved. Borehole radar surveys were conducted in pilot holes drilled at the Moab-Khotsong to assist in the characterisation of the site.

\section{$3 \quad$ Status of experimental sites}

\section{1 Ezulwini Mine}

Ezulwini Mine, approximately $40 \mathrm{~km}$ west of Johannesburg, was opened in the 1960s as the Randfontein No. 4 shaft. It was closed in 2001 and allowed to flood partially. First Uranium reopened the mine in 2006 (First Uranium, 2011). The SATREPS experimental site is located in the shaft pillar (about $500 \times 430 \mathrm{~m}^{2}$ in extent, Figure 5; Table 1), where a package of gold reefs several tens of metres thick is being mined about $1 \mathrm{~km}$ below the surface. The pillar is offset by several strike-slip faults with significant vertical throws whose stability is a concern. The shaft is connected with many tunnels at multiple levels which expose the fault at numerous locations, enabling us to easily construct an initial 3D geological model of the fault system. The Zebra Fault was chosen as the potentially seismically-active fault (green plates in Figure 6), and a network of sensors was designed. Several tens of holes were drilled between February and December 2010, with a total length of about $1 \mathrm{~km}$ (Figures 6 and 7).

Two strainmeters (2.2.4; Figure 5) monitor loading. In order to detect fault instability, a broadband seismometer (2.2.4) was installed in addition to the two strainmeters. A dense network of $27 \mathrm{AE}$ sensors were deployed in 15 boreholes spread three-dimensionally in a $100 \times 50 \times 40 \mathrm{~m}^{3}$ volume (Figure 6), recorded with GMuG system (2.2.5), to delineate the fine structure of faulting. Although much less sensitive than AE sensors, six triaxial accelerometers with much wider response frequency band (three $25 \mathrm{kHz}$ sensors with +/-50 g capacity and three $10 \mathrm{kHz}$ sensor with +/- $15 \mathrm{~g}$ capacity) are installed to calibrate the AE sensors. A transmitter and three receivers are installed to construct a transmitted-wave fault monitoring system (2.2.6; Figure 7). Three sets of sensor boats (Figure 4) were installed to monitor rupture front dynamic stress change (2.2.7). Strain changes associated with mining have already been observed, and the change in the shear stress acting on the fault has been computed. These results are reported to the rock engineering practitioners to support seismic hazard assessments and or stress modelling.
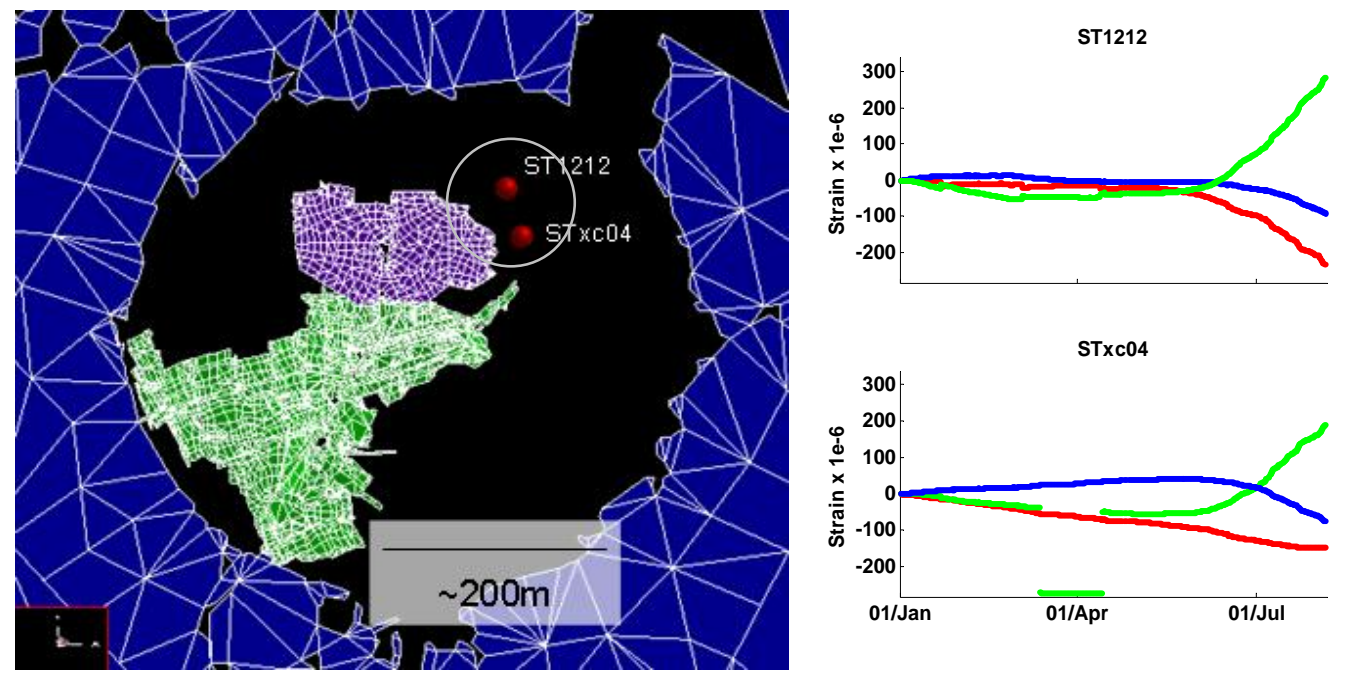

Figure 5 Location of SATREPS experimental site at Ezulwini Mine shaft pillar (left) and strain changes (right). Dense $A E$ and seismic network are deployed in the area marked by a white circle (see more details in Figures 6 and 7). Upward is extension in strain profiles. Arrows show the corresponding changes in principal strains in a plane normal to the borehole axis. Dashed Iines are the intersection lines of the planes parallel to a target fault. $100 \mathrm{e}-6$ corresponds to $5 \mathrm{MPa}$ if $\mathrm{E}=50 \mathrm{GPa}$ in the uni-axial condition 


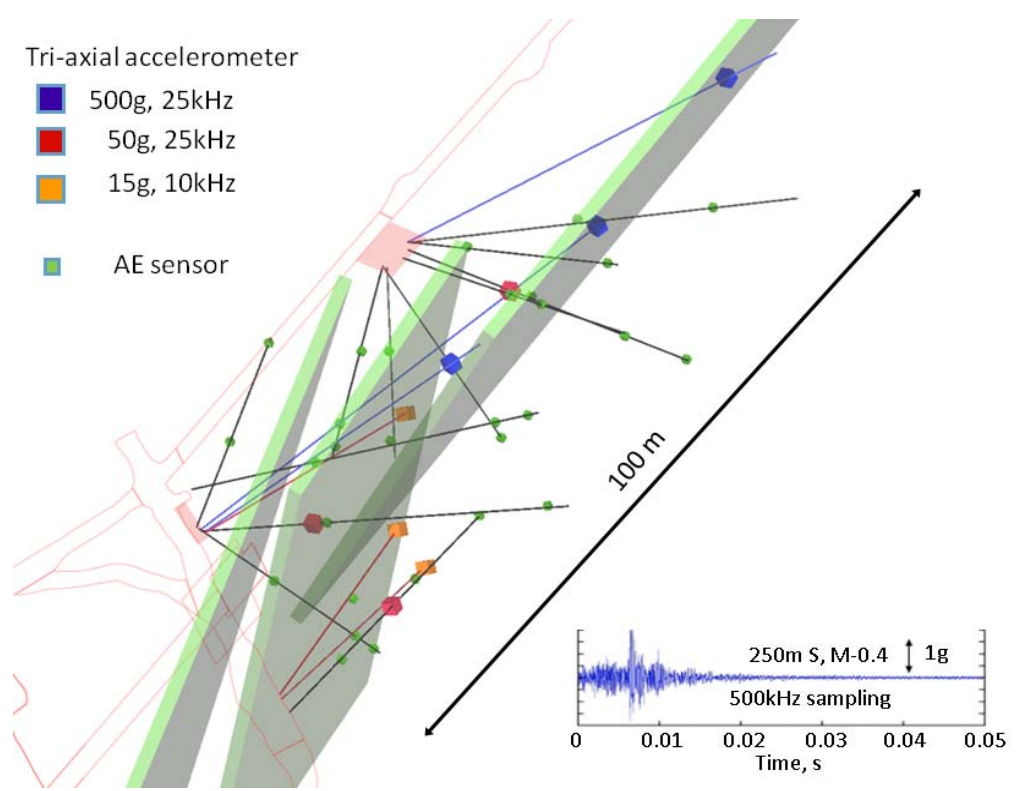

Figure 6 Configuration of AE sensors and accelerometers at Ezulwini Mine (Nakatani, 2011). The inset shows an accelerogram recorded by a $500 \mathrm{~g}$ capacity accelerometer (b/ue) for rupture front experiment (see Section 2. 2. 7, Watanabe et al., 2010). More sensitive $15 \mathrm{~g} 10 \mathrm{kHz}$ accelerometers (yellow) are the receivers for the fault transmission wave experiment (see Section 2. 2.6; Kawakata et al., 2011). $50 \mathrm{~g} 25 \mathrm{kHz}$ accelerometers (red) with less sensitivity but higher frequency are for the calibration of the magnitude of the events picked up by $A E$ sensors

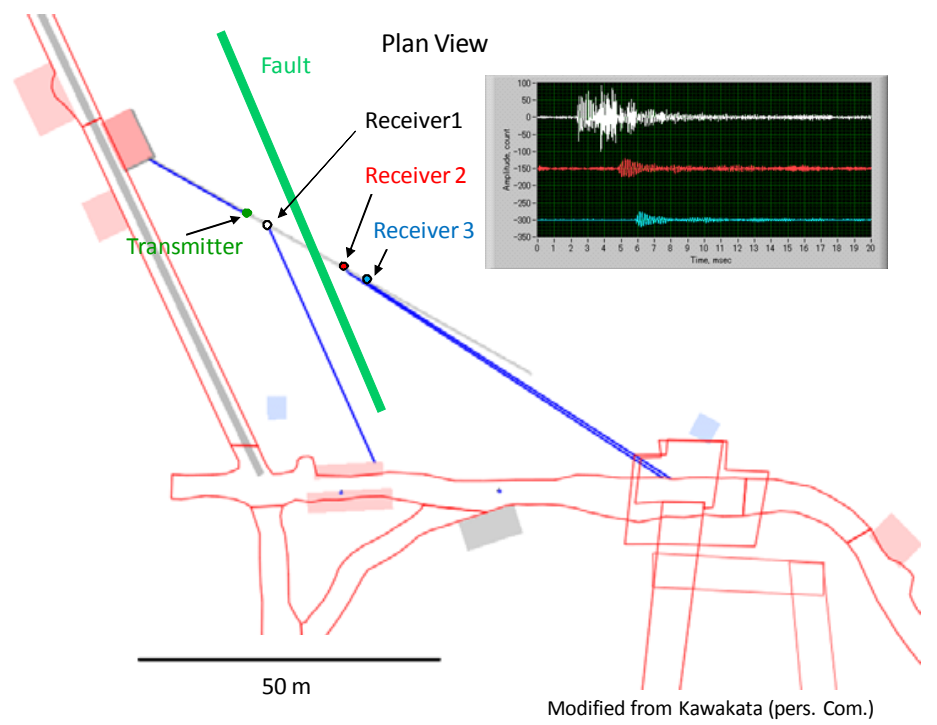

Figure 7 Transmission experimental I ine deployed at Ezulwini Mine and an example of wave forms (Kawakata et al., 2011)

\section{2 Hlanganani Shaft, Driefontein Mine}

Driefontein Gold Mine, located $70 \mathrm{~km}$ west of Johannesburg, has produced more than 100 million ounces of gold during its 50 year life, and still has resources exceeding 50 million ounces of gold. The SATREPS experimental site is located at a depth of about $3 \mathrm{~km}$ (Goldfields, 2011). The Carbon Leader Reef is being mined with dip stabilising pillars. The Leeupoort Fault on Hlanganani Shaft was selected as a potentially seismically-active fault at a depth of about $3 \mathrm{~km}$. The Leeupoort Fault dips to the west-northwest at $73^{\circ}$. The original plan (Figure 8) was to drill 14 boreholes holes from 46 level between the 15 and 16 lines using a return air way and an unused workshop as the base. 


\section{Monitor instability on Leeupoort fault from RAW on 16 tine at $46 \mathrm{~L}$}

A

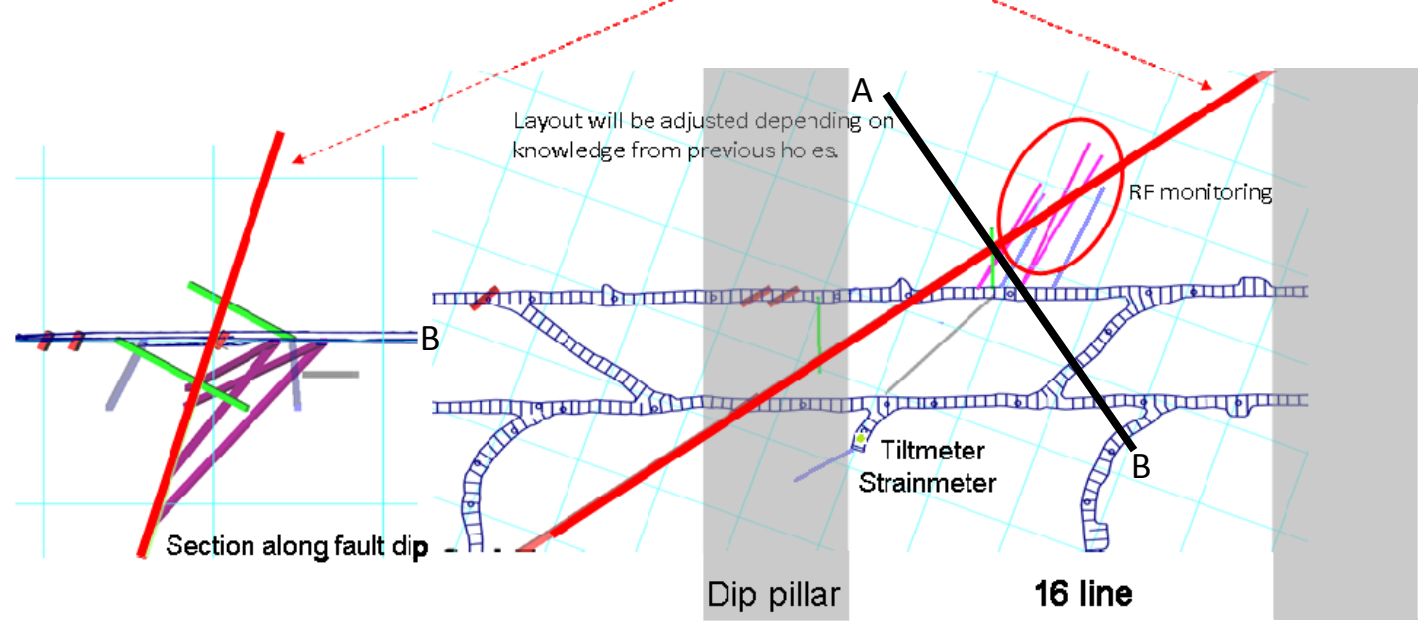

Figure 8 Hlanganani Shaft, Driefontein Gold Mine - each light blue grid spans 25 m

As at January 2012, all drilling has been completed. Two pilot holes (green line in Figure 8) located the fault plane accurately to enable us to finalise rupture front monitoring array (2.2.7; purple lines in Figure 8). Three boats (Figure 5) have been installed and the monitoring has been started in January 2012. As at December 2011, three strainmeters (Figure 3; 2.2.4) had been installed (one at the dip pillar shown in Figure 8 and additional two at another dip pillars and in the rupture front array, respectively). The monitoring of strain was started in December 2011. Tiltmeters, in-stope closure meters and strong motion meters will be installed in 2012. Comparisons of stope strong motion and the strong motion at the seismic source will enable us to evaluate site amplification characteristics of the fractured rock mass. This will contribute to the design of safer support in stopes.

\section{3 Moab-Khotsong}

Moab-Khotsong is one of four mines near the towns of Klerksdorp and Orkney that comprise AngloGold Ashanti's Vaal River operations (Anglogold Ashanti, 2011). The geology of the SATREPS site is characterised by multiple faults that intersect the reef, such as the Cut-off Fault, and by the Die Hoek Fault that underlies the reef (Figures 9 and 10), the instability of which are concerns. Boreholes with a total length of about $1 \mathrm{~km}$ were drilled. Targeting the Die Hoek Fault, an AE network is being established (Figure 10). A GMuG 32-channel system will monitor a network of $24 \mathrm{AE}$ sensors and two $25 \mathrm{kHz}$ triaxial accelerometers covering a $160 \times 100 \times 50 \mathrm{~m}^{3}$ volume. In the volume, a transmitted-wave fault monitoring system, a strainmeter, two broad band seismometers and a tiltmeter are also installed. To monitor instability on the Cut-off Fault, two strainmeters and a tiltmeter are installed in the holes drilled from the cubby J95L-1 (Figure 10). The installation has been hindered by severe damage to the boreholes. In many cases, severe breakouts occur for a good part of the length of the hole, not just the region near the collar, and loose rocks from the breakouts block the holes. In-stope closure meters and strong motion meters will be also installed in 2012.

Borehole radar has not previously proven successful in imaging the Vaal Reef owing to a small contrast in electrical properties between the ore body and country rock. However, it was decided to make use of the holes drilled at the SATREPS site to investigate whether any useful images could be obtained at the site. Observations were carried out in two $100 \mathrm{~m}$ long pilot boreholes in September 2011 using the CSIR Aardwolf40 borehole radar system. Reflections were obtained and are being analysed to establish whether they arise from bedding or the Die Hoek Fault, which is sub-parallel to the bedding. 


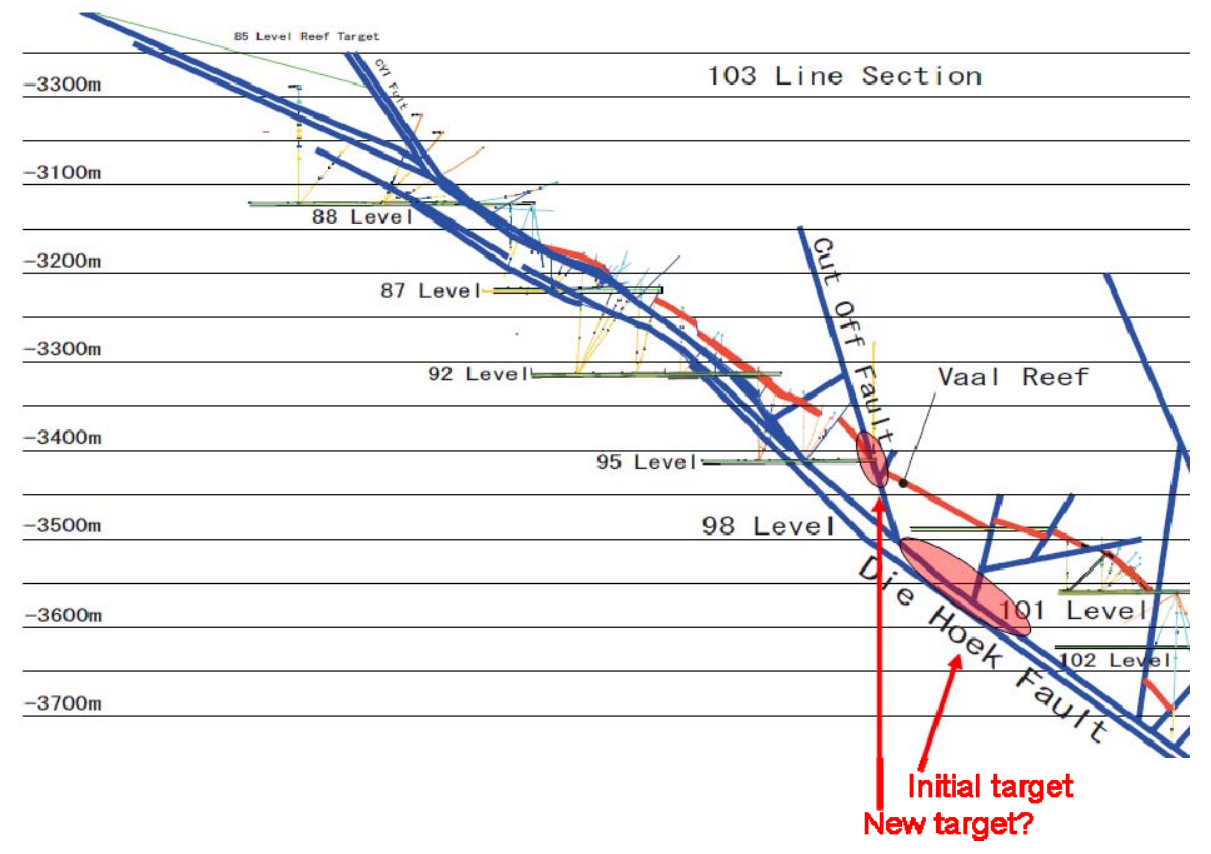

Figure 9 A schematics illustrating the geology at 103 line at Moab-Khotsong Mine. SATREPS main target is the Die Hoek Fault shown by a red ellipsoid. The Cut-off Fault is additionally targeted

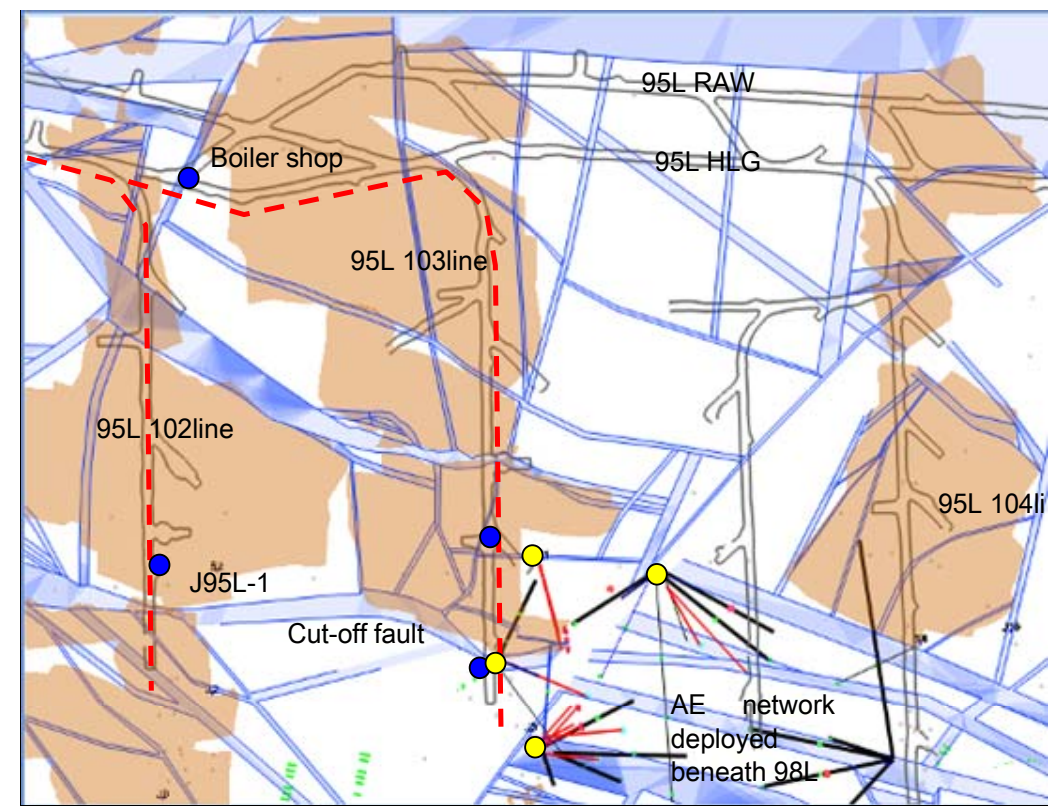

Figure 10 Map (plan view) showing 95 level haulage, return air way, crosscut, faults and route of visit on 25 July 2011 (red dashed I ines). The cubby J95L-1 on 96 level 102 I ine is used to monitor the Cut-off Fault

\section{Conclusion}

The new SATREPS project 'Observational studies to mitigate seismic risks in mines' is a project that aims to address important issues and provide the springboard for new levels of collaboration between Japanese and South African seismologists. It is anticipated that knowledge of earthquake nucleation, rupture and strong ground motion in the near-field will be gained that can be used to mitigate the risks of tectonic earthquakes in Japan. The knowledge will be directly applicable to mining in deep and highly stress conditions. For example, it may be used to upgrade seismic hazard assessment schemes in mines and on the surface, and improve mining layouts and support systems. In addition, the instrumental and human capacity in South Africa will be built. 


\section{Acknow ledgements}

The Japanese-South African collaborative research activities would have been impossible without the assistance from many gold mines and companies providing mine seismology technology and services. In particular we would like to thank Koichiro Miyara, Gilbert Morema, Raymond Vermeulen, Sifiso Khambule, Thabang Masakale, Khanya Luthuli, Dr. Milton Kataka, Martin Lotz and Wian Blom for their daily great effort. Professor Kenshiro Otsuki helped us to construct a geological model. Shigeru Nakao and Takashi Nakayama greatly contributed to installation and monitoring system establishment. We would also acknowledge the dedicated support of colleagues at AngloGold Ashanti (Gerhard Hofmann, Dr Dave Roberts, Lourens Scheepers, Corné Moller), Ezulwini Mine (Luiz Ribeiro, Mike Ward, Lawrence Rwodzi, Johannes Nakana), Moab-Khotsong Mine (Pieter de Bruin, Johan de Bruin, Istvan Nel, Johan Britz, Terry Adams, Peter Schmidt, Lereko Mathibeli), Gold Fields of South Africa and Hlanganani Mine (Koos Barnard, Rob Chaplin, Andre Swanepoel, Mbulelo Ngwenya, Mitch Wiggins, Marius Uys, Kevin Riemer, Nin Naiker), OHMS cc (Vlok Visser, Adri Carsten, Ulandie Steenberg, Bertie Venter, Christo Reyneke), CSIR (Stephens Letlotla, Mpho Nkwana, Pieter Share, Michael van Schoor, Frans Nortje), Ritsumeikan University (Akiko Kamito, Toshiko Tsujita, Aki Komatsu, Tomohiro Fujisawa, Nobuhiro Tanaka, Mayumi Nakagawa, Takako Sagawa and Kumi Tanaka), Seismogen cc (Lyn Ward), IMS (Gerrie van Aswegen, Rudie de Jongh, Errol de Kock, Gareth Goldswain), Murray \& Roberts Cementation, Lesedi Drilling \& Mining Contracting company, Digital Borehole Surveying (Pty) Ltd, JICA (Kaoru Okada, Jun Murakami, Iwao Sakurai, Mami Katsuya, Toshiyuki Nakamura, Ichiro Sato, Shinichi Masuda, Shigeyuki Matsumoto), and JST (Koichi Tsukioka).

The Japanese activities have been partly supported by the Japan Science Promotion Society grant in aid, by the Ministry of Education, Culture, Sports, Science and Technology (MEXT) of Japan, under its Observation and Research Program for Prediction of Earthquakes and Volcanic Eruptions, and by Ritsumeikan University and Tohoku University. The South African activities have been partly supported by the Council for Scientific and Industrial Research, the Council for Geoscience, and Department of Science and Technology through the South African Research Chairs Initiative, and the University of the Witwatersrand.

\section{References}

Anglogold Ashanti (2011) 06 Supplementary information: mineral resource and ore reserve, viewed 31 Oct 2011, http://www.anglogold.co.za/NR/rdonlyres/F8E2F47F-37DF-48C4-8BD8-3F951131AF82/0/reserves_resources_supp.pdf.

Brenguier, F., Campillo, M., Hadziioannou, C., Shapiro, N.M., Nadeau, R.M. and Larose, E. (2008) Postseismic Relaxation along the San Andereas Fault at Parkfield from continuous seismological observations, Science, Vol. 321, doi: 10.1126/science.1160943No. 5895, pp. 1478-1481.

Chen, J-H., Froment, B., Liu, Q-Y. and Campillo, M. (2010) Distribution of seismic wave speed changes associated with the 12 May 2008 Mw 7.9 Wenchuan earthquake, Geophysical Research Letters, Vol. 37, L18302, 4 p.doi: 10.1029/2010GL044582.

Chen, W-Y., Lovell, C.W., Haley, G.M. and Pyrak-Nolte, L.J. (1993) Variation of shear-wave amplitude during frictional sliding, International Journal of Rock Mechanics and Mining Sciences and Geomechanics Abstracts, Vol. 30, pp. 779-784.

Durrheim, R.J. (2010) Mitigating the rockburst risk in the deep hard rock South African mines: 100 years of research, in Extracting the Science: a century of mining research, J. Brune (ed), Society for Mining, Metallurgy and Exploration, Inc., pp. 156-171.

Durrheim, R.J., Ogasawara, H., Nakatani, M., Yabe, Y., Milev, A., Cichowicz, A., Kawakata, H., Moriya, H. and the JST-JICA SA research group (2010) Observational Study to Mitigate Seismic Risks in Mines: a new Japanese-South African collaborative project, in Proceedings Fifth International Seminar on Deep and High Stress Mining, M. Van Sint Jan and Y. Potvin (eds), 6-8 October 2010, Santiago, Chile, Australian Centre for Geomechanics, pp. 215-225.

First Uranium (2011) Ezulwini Mine Operations \& Resources, viewed 31 October 2011, http://www.firsturanium.com/sjfu/view/sjfu/en/page166.

Goldfields (2011) Review of South African operations, Driefontein Gold mine, viewed 18 October 2011, http://www.goldfields.co.za/ops_driefontein.php.

Ishii, H., Yamauchi, T. and Kusumoto, F. (1997) Development of high sensitivity bore hole strainmeters and application for rock mechanics and earthquake prediction study, Rock Stress, Balkema, Rotterdam, pp. 253-258.

JST (2011) Japan Science and Technology Agency, Tokyo, viewed 25 October 2011, http://www.jst.go.jp/global/english/index.html.

Kawakata, H., Yoshimitsu, N., Nakatani, M., Philipp, J., Doi, I., Naoi, M., Ward, T., Visser, V., Morema, G., Khambule, S., Masakale, T., Milev, A., Durrheim, R.J., Ribeiro, L., Ward, M. and Ogasawara, H. (2011) Monitoring transmitted waves across a fault with a high potential for mining induced earthquakes - the Ezulwini gold mine in South Africa, Abstract S31C-2257, AGU 2011 Fall Meeting, 5-9 December 2011, San Francisco, U.S.A.

Lockner, D.A., Walsh, J.B. and Byerlee, J.D. (1977) Changes in seismic velocity and attenuation during deformation of granite, Journal of Geophysical Research, Vol. 82, pp. 6317-6321. 
Lucier, A.M., Zoback, M.D., Heesackers, V., Reches, Z. and Murphy, S.K. (2009) Constraining the far-field in situ stress state near a deep South African gold mine, International Journal of Rock Mechanics \& Mining Sciences, Vol. 46, pp. 555-567.

Lynch, R. (2010) Progress on active seismic monitoring in mines, in Proceedings Institute of Mine Seismology 21st Seminar on the Future of Monitoring the Seismic Rock Mass Response to Mining, 23-24 May 2011, Hermanus, South Africa, shared presentations.

Manthei, G. (2005) Characterization of acoustic emission sources in a rock salt specimen under triaxial compression, Bulletin of the Seismological Society of America, doi 10.1785/0120040076, Vol. 95, pp. 1674-1700.

Milev, A.M., Yabe, Y., Naoi, M.M., Nakatani, M., Durrheim, R.J. Ogasawara, H. and Scholz, C.H. (2010) Coseismic and aseismic deformations of the rock mass around deep level mining in South Africa - Joint South African and Japanese study, Abstract S34B-05, AGU Fall Meeting, 13-17 December 2010, San Francisco, U.S.A.

Nakatani, M. (2011) Monitoring of seismic rupture at the closest proximity in South African gold mines, in Proceedings Outcome Report Symposium of Observational Research Program for Prediction of Earthquake and Volcanic Eruption, 3-5 March 2011, Tokyo, Japan.

Nakatani, M., Yabe, Y., Philipp, J., Morema, G., Stanchits, G. and Dresen, G. (2008) Acoustic emission measurements in a deep gold mine in South Africa-project overview and some typical waveforms, Seismological Research Letters, Vol. 79 (2), $311 \mathrm{p}$.

Naoi, M., Ogasawara, H., Takeuchi, J., Yamamoto, A., Shimoda, N., Morishita, K., Ishii, H., Nakao, S., Van Aswegen, G., Mendecki, A.J., Lenegan, P., Ebrahim-Trollope, R. and lio, Y. (2006) Small slow-strain steps and their forerunners observed in gold mine in South Africa, Geophysical Research Letters, Vol. 33, L12304, doi: 10.1029/2006GL0265076.

Niu, F., Silver, P.G., Daley, T.M., Cheng, X. and Majer, E.L. (2008) Pre-seismic velocity changes observed from active source monitoring at the Parkfield SAFOD drill site, Nature 454, doi:10.1038/nature07111, pp. 204-208.

Ogasawara, H. and Kato, H. (2012) A modified CCBO technique optimised for regular geological drilling procedures in South African gold mines, Stress Measurement Workshop Notes (COR1200), 31 March 2012, Perth, Australia, Australian Centre for Geomechanics, Perth, CD Rom.

Ogasawara, H., Durrheim, R.J., Nakatani, M., Yabe, Y., Milev, A., Cichowicz, A., Kawakata, H. and Moriya, H. (2009a) JST-JICA SA research group, a Japanese-South African collaboration to mitigate seismic risks in deep gold mines, in Proceedings First Hard Rock Safe Safety Conference, J. Van der Westhuizen (ed), 28-30 September 2009, Sun City, South Africa, South African Institute of Mining and Metallurgy, pp. 115-134.

Ogasawara, H., Kawakata, H., Ishii, M., Nakatani, M., Yabe, Y., lio, Y. and the Research Group for the Semi-controlled Earthquake-generation Experiments at deep gold mines, South Africa (SeeSA) (2009b) The Semi-controlled Earthquake-generation Experiments at Deep Gold Mines, South Africa - Monitoring at the proximity to elucidate seismogenic process, Journal of Japanese Seismological Society Series 2 (61), pp. S563-S573.

Ogasawara, H., Takeuchi, J., Shimoda, N., Ishii, H., Nakao, S., van Aswegen, G., Mendecki, A.J., Cichowicz, A., Ebrahim-Trollope, R., Kawakata, H., lio, Y., Ohkura, T., Ando, M. and the Research Group for Semi-controlled Earthquake-generation Experiments in South African deep gold mines (2005) High-resolution strain monitoring during $\mathrm{M}^{\sim} 2$ events in a South African deep gold mine in close proximity to hypocentres, in Proceedings 6th International Symposium on Rockburst and Seismicity in Mines, Y. Potvin and M. Hudyma (eds), 9-11 March 2005, Perth, Australia, Australian Centre for Geomechanics, pp. 385-391.

Ogasawara, H., Yanagidani, T. and Ando, M. (eds) (2002) Seismogenic Process Monitoring, Balkema, Rotterdam, $414 \mathrm{p}$.

Raax (2008) A product brochure of SC200, viewed 31 October 2011, http://www.raax.co.jp/data/pdf/hard/SC200.pdf.

Reches, Z. (2006) Building a natural earthquake laboratory at focal depth, in Proceedings IODP-ICDP Fault Zone Drilling Workshop. Miyazaki, 22-26 May 2006, Miyazaki, Japan.

Sano, O., Mizuta, Y., Murakami, T. and Tanaka, Y. (1997) Sound velocity as a measure of small stress change, Rock Stress, in Proceedings International Symposium on Rock Stress, K. Sugawara and Y. Obara (eds), 7-10 October 1997, Kumamoto, Japan, A.A. Balkema, Brookfield, Vermont, pp. 241- 246.

Sens-Schönfelder, C. and Wegler, U. (2006) Passive image interferometry and seasonal variations of seismic velocities at Merapi volcano, Indonesia, Geophysical Research Letters, Vol. 33, L21302, doi:10.1029/2006GL027797.

Sugawara, K. and Obara, Y. (1999) Draft ISRM suggested method for in situ stress measurement using the Compact Conical-ended Borehole Overcoring (ССВO) technique, International Journal of Rock Mechanics and Mining Sciences, Vol. 36, pp. 307-322.

Van Schoor, M., du Pisani, P. and Vogt, D. (2006) High-resolution, short-range, in-mine geophysical techniques for the delineation of South African orebodies, South African Journal of Science, Vol. 102, pp. 355-360.

Vogt, D. and Van Schoor, M. (2010) The rise of geophysics for in-mine imaging in South African gold and platinum mines, In Extracting the Science: a century of mining research, J. Brune (ed), Society for Mining, Metallurgy, and Exploration Inc., pp. 189-198.

Watanabe, T. (2010) Development of a sensor to monitor dynamic stress change - towards revealing the slip-weakening process of mine earthquakes, Graduate school of Science, Tohoku University, Japan, Masters thesis.

Watanabe, T., Yabe, Y., Moriya, H., Nakatani, M., Kawakata, H. and Ogasawara, H. (2010) Development of a measurement system of dynamic stress change associated with a $100 \mathrm{~m}$ scale faulting in a South African deep gold mine, G-COE Symposium 2010: Earthquakes, Active Tectonics and Geodynamics of Island Arcs, 19-20 February 2010, Sendai, Japan.

Yabe, Y., Philipp, J., Nakatani, M., Morema, G., Naoi, M., Kawakata, H., Igarashi, T., Dresen, G., Ogasawara, H. and JAGUARS (2009) Observation of numerous aftershocks of an Mw1.9 earthquake with an AE network installed in a deep gold mine in South Africa, Earth Planets Space, Vol. 61, e49-e52.

Yoshimitsu, N. and Kawakata, H. (2011) Temporal changes in the Q of broadband P waves transmitting through a fracturing Westerly granite sample under triaxial compressive conditions, Bulletin of the Seismological Society of America, Vol. 101(1), pp. 421-426. 
Yoshimitsu, N., Kawakata, H. and Takahashi, N. (2009) Broadband, P waves transmitting through fracturing Westerly granite before and after the peak stress under a triaxial compressive condition, Earth Planets Space, Vol. 61, pp. e21-e24.

Yukutake, H. (1989) Fracturing process of Granite inferred from measurements of spatial and temporal variations in velocity during triaxial deformation, Journal of Geophysical Research, Vol. 94(B11), pp. 15,639-15,651.

Yukutake, H., Nakajima, T. and Doi, K. (1988) In situ measurements of elastic wave velocity in a mine, and the effects of water and stress on their variation, Tectonophysics, Vol. 144(1-2), pp. 165-175. 
Establishment of SATREPS experimental sites in South African gold mines to monitor

R.J. Durrheim et al. phenomena associated with earthquake nucleation and rupture 